Western University

Scholarship@Western

Law Publications

Law School

2009

The Author as Agent of Information Policy: the Relationship between Economic and Moral Rights in Copyright

Margaret Ann Wilkinson

Western University, mawilk@uwo.ca

Natasha Gerolami

Follow this and additional works at: https://ir.lib.uwo.ca/lawpub

Part of the Intellectual Property Law Commons

Citation of this paper:

Wilkinson, Margaret Ann and Gerolami, Natasha, "The Author as Agent of Information Policy: the Relationship between Economic and Moral Rights in Copyright" (2009). Law Publications. 48.

https://ir.lib.uwo.ca/lawpub/48 


\title{
The Author as Agent of Information Policy: the Relationship between Economic and Moral Rights in Copyright
}

\author{
Margaret Ann Wilkinson and Natasha Gerolami ${ }^{1}$
}

\begin{abstract}
A historical and theoretical analysis of the copyright environment demonstrates that both the economic rights associated with copyright and the moral rights often associated with copyright perform social functions. The latter have not been as universally embraced or adopted as the former. The lack of enthusiasm for moral rights is argued to be because the social utility of this aspect of the copyright regime has gone largely unrecognised. In fact, moral rights ensure that the information needs of the public are being met because they enhance the ability to assess the authority and reliability of information. While historically this has not been as important as enhancing the supply of information, a function performed by the economic rights of copyright, in the context of the new information environment, the role played by moral rights is becoming increasingly important. Our thesis also defines the appropriate scope of moral rights protection in copyright.
\end{abstract}

\section{Introduction}

The use of the identity of the author as an organizing principle, as an indicator of the subject matter and quality of a work, is very much taken for granted by librarians and library patrons. The author's name is generally used to organize books on a shelf, to organize a bibliography and, frequently, to gather together titles in a library catalogue. ${ }^{2}$ In addition, the identity of the author not only aids in classifying works, it operates as an indicator of the subject and quality of the work. The relationship of the author to the text

\footnotetext{
${ }^{1}$ Margaret Ann Wilkinson is Professor in the Faculty of Law at the University of Western Ontario and a graduate supervisor in both Law and Library and Information Science. This work was funded under an Initiatives in the New Economy grant from the Social Sciences and Humanities Research Council of Canada. Natasha Gerolami is a doctoral student in Library and Information Science at the University of Western Ontario. Research assistance has been provided by law students Anna Milot and Vanessa Bacher. 2 The primacy of the author as an access point is reflected in the fact that author is used as the "main entry" according to the Anglo-American Cataloguing Rules. Of course, the use of main entry may be less important now that catalogues are online and hyper-links are used to connect files (see Bowman, 2003, p. 7). Nevertheless, the author's name still functions as a tool to bring all titles by one person together. Authority control, which ensures that one authorised form of an author's name is used consistently, is still necessary to organise this collocation of works according to author in order to access material.
} 
is drawn upon frequently when evaluation of a work is being conducted. Collections librarians use the authority of the author as one of the guiding principles when making acquisition decisions or evaluating reference tools (Katz, 1997, p. 26). Consideration is given to the reputation, experience and credentials of the author. These characteristics of the author are assumed to have a direct bearing on the quality of the work.

The identity of the author, therefore, has always played a dual role in library and information science. The author is used to aid access and bibliographic control by operating as one of the access points and organizing principles in catalogues, indexes, bibliographies and other reference tools. At the same time, the identity of the author operates as an indicator of the quality and reliability of a text.

Laura Gasaway notes the centrality of the author in both copyright law and in the library (Gasaway, 2003). Societal recognition and respect for the author's work, she argues, can justify and explain copyright. It can also explain librarians' use of the author's identity as an organizing principle and mechanism for quality control. ${ }^{3}$

Despite Gasaway's observation, the economic rights of copyright, ${ }^{4}$ though identified with an author, do not, in and of themselves, protect the relationship between the author and the text. The economic rights grant the copyright holders exclusive rights to make various uses of a work including copying, publishing, performing, translating and adapting the work. The economic rights are granted to the author upon creation of the work and last for the life of the author plus 70 years (in the United States and also

\footnotetext{
${ }^{3}$ It will be argued here that the elements of recognition and respect that Professor Gasaway argues justify the economic rights in copyright better justify moral rights in copyright - precisely for the same reasons that they function as a mechanism for quality control in library and information science.

${ }^{4}$ The term "economic rights" will be used throughout to distinguish the original concept of copyright from the later concept of moral rights.
} 
generally in Europe) or life of the author plus 50 years (in Canada) ${ }^{5}$. These rights are transferable and, therefore, the author, at any given time, is not necessarily the rights holder. ${ }^{6}$ There is another set of rights in copyright, granted in some jurisdictions, which are retained by the author even when the economic rights have been transferred to others: the moral rights. ${ }^{7}$ The two most basic moral rights are the right of paternity, which permits authors to object if their names are not used in association with the work, and the right of integrity, which permits authors to object to any modification, mutilation or distortion of their work that prejudices their honour. Moral rights, at a minimum, thus allow an author to insist that his or her name will be attached to the work and that the work will not be altered in any way that affects the reputation of the author.

In a time in which technology permits the easy transfer and modification of works, moral rights will become increasingly important. Gasaway argues convincingly that changes in technology are making it more and more difficult for users and intermediaries, such as librarians, to assess the authority and reliability of works available in digital format (2003, pp. 1222-1223). The fact that texts appear and disappear with regular frequency, the difficulty in assessing the origin, author or publisher of the work, and the continual modification of on-line texts by various individuals create extreme difficulties in the authentication and preservation of works. For this reason, legal provisions for moral rights provisions may be more important than ever in preserving the relationship between author and text. Moral rights protection, frequently seen as personal

\footnotetext{
${ }^{5}$ This is the minimum required protection according to the Berne Convention.

${ }^{6}$ Indeed, copyright statutes can vest initial ownership of a copyright interest in someone other than the author. Under the Canadian statute, in an employment situation, the initial ownership of the economic rights in copyright vests with the employer even though the employee may be the author of the work (see Copyright Act, s.13.(3)).

${ }^{7}$ In the original French, the term does not carry the connotation of "ethical" that "moral" does in English: it simply connotes a relationship to an individual personality.
} 
rights for authors to protect their reputations, should be recognised as playing an increasingly important public function. As concern over efficient access to quality information grows, there should be greater recognition that, though distinct from the economic rights in copyright, legal protection for the moral rights of authors can play just as important a role in providing a balance between private rights and the public's interest in information flow as has been traditionally attributed to the economic rights regime in copyright.

The stated purpose of copyright has long been taken to be to encourage the production and dissemination of works thereby increasing access to information. The following historical overview of the development of the economic rights in copyright and of the moral rights will demonstrate that the two systems of rights function in complimentary, though distinct, manners. In both cases, private rights to control and benefit from works are ultimately enshrined by law, to the benefit of the public. We will demonstrate that traditionally the economic rights regime has been conceived of as a balance between owners' rights to benefit financially from the exploitation of the works and users' rights to benefit from access to the works. The economic rights in copyright are fashioned as an incentive for authors to create and disseminate their works (Vaver, 1991, p. 127). ${ }^{8}$ The intention of the legislation that created them is to balance owner and user rights and promote access to information, free speech, and education; ensuring that users are not unduly estopped from access to works. We will argue that the moral rights in copyright also help to ensure that the information needs of the public are being

\footnotetext{
${ }^{8}$ In the economic copyright regime, further interests of the public are recognized through certain exceptions to the interests of the economic rights holders: user's rights provision. In Canada, for example, certain exceptions, including the fair dealing provisions, are provided in the Copyright Act which permit users to copy and use works without violating the economic rights holders' rights. In the United States similar exceptions exist as fair use.
} 
met. The difference is only that the expanding role moral rights can play in the new information environment has largely gone unrecognised and has not been clearly articulated. Indeed, this lack of recognition and articulation is so extensive that Patrick Masiyakurima concludes " $[\mathrm{t}]$ he trouble with moral rights is that no single theory can explain the purposes of moral rights protection convincingly" $\left(2005\right.$, p.432). ${ }^{9}$ However, we will establish that there is a single explanation that justifies and encourages the provision of moral rights protection in law. That explanation is the need for indicators of authority in information sources. We argue that it is necessary to identify and discuss this public utility of the moral rights regime, as an information policy issue, in order to establish the appropriate scope and limits of these rights.

\title{
2. The Characteristics, role and history of the economic rights in copyright
}

\author{
(a) Enhancing the supply of information
}

\footnotetext{
9 The concept of authority developed here is quite different from Masiyajurima's "authenticity," one of his four possible explanations for moral rights. Even he says his concept is very similar to another of his four, "the cultural heritage argument." He describes his notion of authenticity as "a hybrid interest designed to preserve the economic benefits of copyright transfers, the rights of consumers and the public interest in maintaining accurate artistic records" ( p.428). The concept of authority being described here is one which functions as a necessary attribute of every kind of information and which contributes to the ability of those seeking information to discriminate between available sources, each of which appears to provide information in satisfaction of a particular need but yet differs from other available sources. Accuracy and reliability under our conception of authority, derived from library and information science, may be maintained by keeping the record unaltered but may also be preserved where a record is altered in a way sanctioned by the author: a key component of the authority is the authority of the author, not necessarily the authority of a particular document, except as connected with the author's control over it. The other two explanations that Masiyakurima canvasses are personality, also discussed herein, and freedom of expression. His connection with freedom of expression is that exercise of moral rights permits authors to be recognized as participating in discourse and prohibits others from falsely claiming ideas (paternity) and also permits authors to control distortion of their ideas (integrity). However, we must point out that since moral rights attach to expressions, not ideas or facts, just as the economic rights in copyright do, it cannot be claimed that freedom of expression values are uniquely or even best served within the copyright framework by the moral rights provisions. It is the separation of both economic and moral rights (by attaching them both only to expressions) from the underlying facts and ideas that really guarantees freedom of expression.
} 
In order to fully comprehend how moral rights provisions fit theoretically within the larger scope of the copyright regime and the broader policy frameworks surrounding information, we must first understand the role of economic rights in copyright. The task is rendered more difficult by the fact that legal scholars continue to debate the theoretical foundations and function of economic rights in copyright. Certain writers believe that copyright is granted to authors as a reward for their labour (Moore, 1997, and Drassinower, 2003). Other theorists have argued that copyright is granted to authors because of the romantic conception we have of authorship. This conception of the author came to prominence during the Romantic movement of the eighteenth century. It emphasises the intimate relationship between the author and the work (Aide, 1990, p. 212). The expression in an artistic or literary work was deemed to be imbued with the essence or personality of the author, her or his originality and genius, and the author should therefore be granted permission to control the creation (Boyle, 1996). Alternatively, there are scholars who subscribe to the utilitarian theory of economic rights in copyright. Copyright is a means to an end. The government wants to encourage the production and dissemination of information and therefore it provides the legal devise of copyright as an incentive to authors to write or create (Vaver, 1991, p. 127).

In North America, state adherence to utilitarian principles is explicit in government policy instruments. Most frequently, American legal scholars refer to the Constitution of the United States of America which states that copyright is a limited term monopoly granted for the purpose of "promoting the progress of science and the useful arts” (U.S. Const. art.I, §8, cl.1). This clause in the Constitution justifies copyright by maintaining that it is an incentive structure to promote the production of socially valuable 
works. ${ }^{10}$ In Canada, this position has been articulated in the courts. Justice Binnie of the Supreme Court, speaking for the majority of the Court in the recent case of Théberge v.Galerie d'Art du Petit Champlain Inc (2002), commented:

The Copyright Act is usually presented as a balance between promoting the public interest in the encouragement and dissemination of works of the arts and intellect and obtaining a just reward for the creator (or, more accurately, to prevent someone other than the creator from appropriating whatever benefits may be generated).

This utilitarian position in Canadian and American government is consistent with the history of copyright. Economic rights in copyright historically were drafted as private rights, granted to authors, which served the public interest.

\section{(b) Historical origins in England}

Lyman Ray Patterson (1968) demonstrates that the Statute of Anne, titled an An Act for the Encouragement of Learning and for Securing the Property of Copies of Books to the Rightful Owners Thereof and considered by some to be England's first copyright legislation and the first codification of authors' rights in law, was not, in fact, an acknowledgement of the rights and rewards due an author. Patterson notes that there is little in the original statute to suggest that the rights of the author were of primary importance. It is far more likely that the legislation was intended to regulate the book trade. Prior to the enactment of the Statute of Anne, the members of Stationers' Company (the booksellers' guild) were the only individuals who had rights to hold copyright in

\footnotetext{
${ }^{10}$ It should be noted that the copyright referred to in the American Constitution is the economic rights in copyright: as will be evident from the following discussion, the Constitution pre-dates the concept of moral rights in copyright.
} 
works and copyrights existed in perpetuity. The limited copyright term given by the Statute of Anne was to help break up the monopolies that had previously been created in the book trade. Moreover, under the Statute of Anne, copyright was limited to a period of years, after which works would again be freely available in a competitive marketplace free of monopoly interest (Patterson, 1968, p. 144). The concept of the author as creative genius, therefore, was not what was being recognised in this legislation): "the author was used primarily as a weapon against monopoly." (Patterson, 1968, p. 147) ${ }^{11}$ Ultimately, whether it was consciously a part of the strategy of the drafters of the statute or not, the result was that a greater number of texts were made available to an increasingly literate public.

The ingenious idea that was codified by the Statute of Anne (McKeown, 2000, p. 24) was to give those who needed to invest in the machinery of the new industrialized information industries an incentive by separating the facts and ideas behind texts from the form of the texts themselves. This both fit the public perception of information in England as a free prerogative of every Englishman (the first part of the title of the act: An Act for the Encouragement of Learning...) and ensured the free flow of information to fuel the creativity necessary to ensure scientific and industrial progress (Randall, 2001, p. 51). ${ }^{12}$ On the other hand, by legislating individual rights attaching to aspects of the industrial production of information products, it was possible to create an economic environment of monopoly incentives for those investing specifically in the machinery of text production (the second part of the statute's title: ... and for Securing the Property of

\footnotetext{
${ }^{11}$ Indeed, it also appears unwise to rest the theoretical justification for copyright on such a basis, quite apart from the evidence of the historical record, because the romantic view of the author is falling out of favour with literary theorists. (Rajan, 2002, p.193).

${ }^{12}$ Marilyn Randall describes the notion of the author developing during the Romantic period into a concept of the author as sole source and origin of her or his own discourse.
} 
Copies of Books to the Rightful Owners Thereof [emphasis added]). This ensured that enhanced flow of information in society would actually be accomplished using the new technology of industrialization because those investing in information technology would be rewarded.

Using the device of the identification of the work with its author in order to identify and control copying of the work was timely. The emphasis on the copies, rather than on the works themselves, in the statute's title, emphasizes the focus on the right to copy rather than on the author's rights. The right created has been described as "the exclusive right of multiplying copies of an original work or composition, and consequently preventing others from so doing" (Chappell v. Purday, 1845, p.316, per Pollack,C.B.). The concept created the necessary rewards for investment in the dissemination of the new ideas that would further the national economic growth of the capitalist state and keep Britain economically at least abreast, if not ahead, of its European competitors. ${ }^{13}$

\section{(c) Historical origins in France}

The development of the English economic rights in copyright as a trade regulation devise is echoed virtually simultaneous development in France of

\footnotetext{
${ }^{13}$ Canada and the United States share a common heritage in copyright until the Independence of the United States from Great Britain. From then on, the experience of copyright in the two jurisdictions begins to diverge. The United States, an information importing country after its Independence, included copyright in its Constitution (as discussed below) and created a form of copyright very early in its history, 1790, but did not extend that protection to foreign works until 1954 (and even works by foreigners manufactured in the United States were not protected in copyright in the United States until 1891). On the other hand, Canada, formed almost a century later, in 1867, continued as a colony and then dominion, and thus continued to be influenced directly by the British experience until the 1920's. By this time Canada and Britain were members of the international copyright community of the Berne Convention (which, as discussed below, the United States did not join until much later). Although still officially a colony of Britain until 1931, after 1920, Canada began to develop its own copyright environment, influenced by its past, by the Berne Convention, and by the languages of its own statute (which was enacted in both English and French).
} 
economic rights in copyright, the law of droit d'auteur [literally, "law of the author"]. ${ }^{14}$

Carla Hesse outlines the debates in revolutionary France that culminated in the development of its copyright legislation (1990). It has been commonly held that authors in France were granted limited copyright in their works out of recognition for their role in the creation of knowledge. In order to challenge that presumption, Hesse examined the contemporary debate that raged between Denis Diderot and Marie-Jean Antoine Nicolas de Caritat, Marquis de Condorcet. The former argued that ideas emanate from the author, and therefore the author should have unlimited property rights to her or his work. The latter argued that ideas exist in nature and the author is merely the medium for communicating those ideas to the public. The author, under this latter perspective, is accountable to the public and should not have property in ideas. Hesse demonstrates that the French legislation drafted after this debate was a compromise between these two positions. French copyright legislation, although known in France as droit d'auteur, was not created to reward the genius of the author.

Hesse argues the abolition of the privileges of the publishers in France, which had existed in the pre-revolutionary ancien regime, in favour of a limited economic right in copyright was actually done in the interest of the public, not out of respect for the personal rights of the author (1990, p. 130). The elimination of the royal "privilege" system, in favour of "property" rights,

\footnotetext{
${ }^{14}$ The Canadian copyright legislation is called, in English, the Copyright Act and, in French, Loi sur le Droit d'Auteur. Both the English and French texts of the law are official.
} 
actually resulted in a loss of power and control for the French publishers. The beneficiary of the change in legislation was the public. Hesse suggests that these new author rights were understood to be serving the public interest.

The post-revolutionary changes to the French legislation governing theatrical works are prime examples of Hesse' premise. The authors of theatrical works lobbied for the abolition of the system of privileges since it favoured the publishers, not the public. They asked for copyright in their names, in the interest of the public.

The authors represented themselves as servants of the public good, of its enlightenment, in opposition to the private interests of publishers and theatre directors. Thus the authors themselves rejected the Diderotist argument...[and] presented themselves as contributors to "public property and guardians of the public claim to the nation's cultural commons (Hesse, 1990, p.126).

The significance of the playwrights' position is not only their concern for the public interest but that they position themselves between the publishers or theatre directors and the public. They saw themselves as mediators between a cultural commons, belonging to the public, and those who were attempting to benefit from a monopoly in texts.

\section{(d) Why a legal response to economic change was necessary}

We have established the public interest in the economic rights in copyright (droit d'auteur) from their historical roots in both England and France but, further, we will 
argue that it is this public interest in the economic rights in copyright which determined their timely appearance in history. Copyright began as an artificially created legal response to changing economies in Europe (Bettig, 1996, p. 11, 16). ${ }^{15}$ The immediate economic stimuli for the creation of economic rights in copyright and the regime of patent are the print revolution and the industrial revolutions, respectively. It must be noted that the two revolutions were inextricably connected and that the printing press was as much an artefact of industrialization in its revolutionary impact on text as any other invention of the industrial revolution was in its economic sector (Randall, 2001, p.65). ${ }^{16}$ The radical effects of the printing press on European society have certainly been noted (Eisenstein, 1979) -- but its impacts on two different elements of communication have not been as well understood in subsequent analysis: the elites controlling the flows of information and the channels through which audiences were best reached.

William Caxton is commonly credited as the first to introduce the printing press into England in 1476. At first, foreign presses were encouraged. For example, between 1484 and 1533, a statute regulating and restricting foreign businesses in England had an exemption for printing and bookselling (1 Rich. III, c.9). However, this was shortly replaced by attempts to encourage and protect the indigenous press industry by licensing beginning on November 16, 1538 under Henry VIII (Steele, Procl. No.176). In May 1557, the Stationers' Guild was given a royal charter and charged with maintaining the monopoly over printing and publishing in England. This system culminated in the

\footnotetext{
${ }^{15}$ Ronald Bettig does trace roots for copyright back to the Roman publishing system but agrees that the role of copyright in the European context was an advent of the invention of the printing press in 1450.

${ }^{16}$ Our current economic environment has similarly been termed both the post-industrial age and the information age. Both the printing revolution and current information age have begun with text and then moved to affect the distribution of artworks and musical notation (in the case of the printing revolution) and music itself (in the case of the information age).
} 
Licensing Act of 1662 (13 \& 14 Car.II, c.33). These early efforts to require printing presses to be licensed were attempts to continue the control of the channels of communication of texts by the existing elites: to continue control of those communications that were not immediate in terms of time and place, that is, communications that were not oral, or at least aural, and to limit them to the existing elites. John S. McKeown states:

...in response to the divergence of religious belief during the Reformation, the clerics came to rely on printing as a means to control doctrine and prohibitions. In 1401 a statute was passed for the suppression and punishment of heretical writings and in 1529, Henry VIII published a list of prohibited books, followed by a proclamation relating to religious books the next year.... One of the first official acts of Elizabeth after her accession was the issue in 1558 of a proclamation requiring the burning of all heretical books (2000, p. 15-16).

This proved impossible - and, indeed, the economic revolutions, of which the print revolution was a part, ultimately ended up redefining the elites themselves throughout Europe. The new elites were based upon ownership and control of the engines of industrial production rather than upon ownership and control of agricultural production and land (Beattie, 1987, p. 22).

\section{(e) The effects of the economic rights in copyright}

Recognition of the controlling elites of the new engines of information production began through the legal creation of the copyright. Through the legal fiction of the 
copyright, the investment required for the industrialization of the dissemination of text was encouraged and protected - but the economic rights of copyright did not secure to the copyright holders the exclusive right to communicate particular information - only to communicate a particular container (text or artwork) of that information. ${ }^{17}$

The largest possible audience for texts and artworks after the printing press was invented was the audience that was available once the work was identically replicated through the printing press. Copyright boosted the value of this replication by ensuring that each work had a national monopoly to exploit. The only way to fully exploit the creation of a work is to reach the largest possible market: most authors and artists have chosen to avail themselves of the possibilities created by the industrialization of the production of the containers of information. ${ }^{18}$ Since the artists and authors usually did not control the new print technology, their access to its possibilities was indirect, through the industrialists who did control it. Since, with the demise of the old elites, access to

${ }^{17}$ Other competing containers of that same information were not precluded - and, indeed, were equally encouraged. On one level, there was a reality and a benefit in this encouragement of multiple containers of the same information, particularly since, at this stage, all the containers of information were representational. There were real differences between the texts of speeches as reported, for example, and the words as delivered. There were real differences between a scene viewed and the paintings rendered by various artists from those scenes. And only the representations could be captured and conveyed to audiences distant in time or in space - not the actual speeches or images themselves. Since only the representations could be captured before sound recordings and photographs were invented, copyright was created to attach to the representations: the works. And the representations were the complete universe of subject matter available to the then fledgling publishing industry. Copyright did have an effect on the control of channels of communication: each work's, or expression's, or container's, channel was controlled almost exclusively by that container's copyright holder. But since there could be multiple containers for any given idea or fact, there was no exclusive control over channels for distribution of particular information. As the technology of the sound recording and the photograph emerged, there was scepticism in many quarters about whether they deserved copyright protection: only very gradually and grudgingly did the international community come to accept them as appropriate subject matter for copyright: for example, photographs were not included as fully protected works in the original Berne Convention of 1886 and continued as less than fully recognized for decades afterwards.

${ }^{18}$ Certainly, with the demise of the old elites, the best access to support for the artists and writers was to access the new elites: the industrialists, who, in turn, recouped their investments in "their" artists and writers and in their publishing technology by accessing the new mass audiences available through publishing. This, of course, meant most artists and writers chose to indirectly profit from the newly enlarged audiences for their work by, also indirectly, accessing the technology of publishing. 
aristocratic patrons for artists and writers was virtually extinguished, the best access to support became access to the new elites. In turn the industrial printers and publishers recouped their investments and their business risk in "their" artists and writers and in their publishing technology by accessing the new mass audiences available through publishing. What they demanded of "their" artists and writers, in return, was assignment of those artists' and writers' copyright interests.

The many aspects of the copyright holder's control can be seen in the rights copyright law has given to them: the right to copy, the right to adapt, the right to perform, and so on. The original copyright holder can transfer each of these rights to others. Thus copyright enables a whole network of channels for distribution of an author's work - and control of each channel can rest with a different copyright holder. On the other hand, since there can be multiple containers, or works, for any given idea or fact, even the network of control associated with a given work does not create exclusive control over the channel for distribution of particular information. ${ }^{19}$

Publishing technology became widespread in society because there was an incentive created through copyright for investing in it. The way that copyright created an incentive for the industrial production of text (and then, somewhat later, for industrial production of musical scores and art reproductions) was to artificially create a scarcity in

\footnotetext{
${ }^{19}$ The extension in the United States of the copyright legislation to include regulation over the contents of databases through the Digital Millenium Copyright Act 1998 [DMCA] challenges the traditional distinction in copyright law that ideas and facts must be allowed to circulate freely in society. Many would argue that the DMCA, although located within copyright legislation, is law of a different nature. Canada has so far refrained from altering its copyright legislation to include DMCA-type provisions, although it has signed the World Intellectual Property Organization Copyright Treaty of 1996 which, some argue, requires DMCA-type provisions. In Canada, Bill C-60, An Act to Amend the Copyright Act, introduced June 20, 2005 would have introduced American-style protections, particularly in ss. 27 and 34, but failed to pass before Parliament was dissolved. Canada's Parliament is currently considering Bill C-61 An Act to Amend the Copyright Act, which passed First Reading June 17, 2008. If passed, it would introduce a unique version of technological protection measures. The discussion of the idea/expression dichotomy herein focuses on copyright as originally conceived - before the WIPO Copyright Treaty.
} 
the underlying work upon which the copyright holders could then capitalize. This was by initially identifying each work uniquely with its author. However, once an artist or writer who held the original copyright chose to access the industrial tools of publication, as described above, the artist or writer was almost invariably required by the new industrial elite, those who controlled the presses, to give up control of the original work. A petition presented to Parliament in 1709 echoed exactly this situation:

It has been constant usage of the writers of books to sell their copies to booksellers, or printers, to the end they [the printers and booksellers] might hold those copies as their property, and enjoy the benefit of making, and vending, impressions of them: yet divers persons have of late invaded the properties of others by reprinting several books, without the consent and to the great injury of the proprietors [again the booksellers and printers], even to their utter ruin, and the discouragement of all writers in any useful part of learning ( McKeown, 2000, p. 24, quoting Jo. H.C. xvi, 240a).

The regime of economic rights in copyright appears to have survived precisely because it favours those who have become the dominant elite: the industrialists. Production of text, musical scores and artwork became industrialized just at the dawn of the period during which those who controlled industrial processes have become the elite - and copyright first ensured the transition of text production to an industrialized process and then has served to maintain the economic viability of that production.

Eventually, in the late nineteenth century, the dominance of copyright as an effective vehicle for advancing national economic agendas was signalled by 
the creation in 1886 of the international Berne Convention for the Protection of Literary and Artistic Works. The crux of the Berne Convention was the agreement between member states that a work entitled to the copyright monopoly in one member state would be respected as copyrighted in other member states (the principle of national treatment) and that copyright holders would be entitled to the same minimum rights set out in the treaty in all member states. Thus the principle that an original work carries with it a national monopoly over certain uses for a period of time became extended to create a system of international monopoly among member states.

Joining Berne was advantageous for information-exporting countries.

The United States, which was, in the nineteenth century, still an informationimporting nation, did not join the Berne Convention, although its Constitution recognized copyright and it had created a domestic copyright regime..$^{20}$ Nonetheless, as Sam Ricketson points out:

Despite [its] relatively limited membership, the geographical sweep of the new Union was considerable when account is taken of the colonial possessions of France, Germany, Italy, Belgium, Spain and the U.K.... [As late as 1987] it still ... retains clear evidence of its Old World origins and orientations (Rickets on, 1987, p. 79-80).

Shortly after joining the Berne Convention in 1989, the United States, now an information-exporting country, was instrumental in bringing the provisions of the Convention pertaining to the economic rights in copyright into the international trade

\footnotetext{
${ }^{20}$ Indeed, the United States did not join the "Berne" community until it realized, in the last quarter of the twentieth century, that it had become a net exporter of information (Samuels, 2000, p.7).
} 
environment of the newly formed World Trade Organization. TRIPS (Agreement on Trade-Related Aspects of Intellectual Property Rights), which is appended to the World Trade Organization Agreement of 1994, incorporates most of the Berne Convention by reference (Article 9(1)), bringing the principles of the economic rights into a still larger community of nations (virtually all nations) and adding the coercion of trade sanctions to ensure that its provisions are implemented in each country's domestic laws.

This history demonstrates that although there is a robust rhetoric surrounding the concept of the author in the economic rights sphere of copyright, and although it is true that the author is fundamental to the conception of the economic rights in copyright, the identification of the author with the work in relation to the economic rights in copyright really functions to uniquely identify the work, as the identity of the author functions in librarianship in its role as an aid to access and in bibliographic control. The history of these economic rights demonstrates that, through assignment, the industrial elites routinely end up with control over these rights in works, rather than the authors and artists - which is exactly what these economic rights were specifically designed to do when created in eighteenth century Europe. ${ }^{21}$

These older and original aspects of copyright, the economic rights, therefore, demonstrably cannot function to protect the relationship between the author and the text: once the author has assigned the economic rights, or in situations where the author was never given the statutory right to control the economic rights, the author loses control over these aspects of the work. Thus economic rights cannot, in and of themselves,

\footnotetext{
${ }^{21}$ In current copyright law, moreover, authors are surgically and completely removed from active participation in the economic rights environment by provisions that vest the copyright in employment situations with the employer, not the employee. In the United States, the vesting applies to an even larger group than in Canada: to all "works made for hire."
} 
function to support either use of the author's identity as a mechanism for quality judgements about the work or reliance upon the author to control the integrity of the work as initially conceived. Those who seek indications of the authority for information presented in a work must look elsewhere.

\section{The Characteristics, Role and History of the Moral Rights in Copyright}

\section{a) Historical origins}

Moral rights for authors, unlike the economic rights in copyright, have only fairly recently come to be recognized: they can be traced back to the mid-nineteenth century in French case law (Sarraute, 1968, Goudreau, 1993, p. 405).

Until the twentieth century, there were no moral rights recognised in North America. The earliest copyright legislation affecting Canada did not include any aspect of moral rights protection. The current Canadian Copyright Act, when it was first passed in 1921 and came into force in 1924, included no aspect of moral rights protection. Beginning the year that new Copyright Act came into force, there were repeated, unsuccessful, attempts made to add moral rights protections to the Canadian legislation —in 1924, 1925, 1926, and 1927 (Canada).

Internationally, moral rights only came to be included in the Berne Convention when it was revised at the Rome Conference in $1928 .^{22}$ At that Conference, the Italian

\footnotetext{
${ }^{22}$ Even as early as 1928 it was noted that: "it is henceforth beyond doubt that the creator of a literary and artistic work retains rights in the product of his intellectual effort that are above and outside all agreements on disposal. Those rights, which for want of a more adequate expression are called moral rights, are distinguished from economic rights, and assignment of the latter leaves the former intact [italics added]." (International Union for the Protection of Literary and Artistic Works, 1986, p.165).
} 
delegation drafted the most comprehensive proposal for the inclusion of moral rights

(Ricketson, 1987, p. 106, 460). In so doing, they described these rights as follows:

It should be mentioned that the shift of focus that has occurred in legal doctrine in favour of the protection of personal copyright has recently taken on a more general, more uniform and more precise character, in spite of the divergent theories on the nature of copyright $(\ldots)$ it is agreed today that, independently of the exclusive rights of economic character, which are essentially temporary and transferable, the author does own one right, or a set of rights strictly inherent in his person, that are intransferable and without limitation in time, and which mainly concern the absolute right to publish or not to publish the work, to recognition of authorship and finally to the protection of the integrity in the work... (International Union for the Protection of Literary and Artistic Works, 1986, p. 163).

The Subcommittee on Moral Rights for the 1928 Conference reported and recommended adoption of much of the Italian delegation's memorandum but only incorporated the right of attribution or paternity and the right of integrity into its proposed text for moral rights protection. ${ }^{23}$ The right of

\footnotetext{
${ }^{23}$ Indeed, one concern that is raised about moral rights is that there are a number of rights that are claimed in various jurisdictions to be moral rights but are not found in other jurisdictions; for example, the right of divulgation, the right of withdrawal (to remove the work from the public), the right of association (of the work with certain causes or products, of which there will be further discussion below). One of the functions of this analysis will be to determine which rights contribute to the information policy object here claimed for moral rights in copyright. This is not to say that other rights should not be legislated, but only to say that such legislation should not form part of the moral rights in copyright and must therefore be justified on other grounds. Both the rights currently provided for in the Berne Convention, as will be seen, contribute to the information policy object here outlined for moral rights in copyright.
} 
divulgation or disclosure (the right to publish or not publish) was excluded from the final draft, as a compromise over the emerging divergence between views of copyright as essentially property based and views of copyright as essentially personal rights (Goudreau, 1993, p. 409).

While it is plausible that the right of divulgation may be implicit in the Berne Convention rights which have been expressly articulated (Ricketson, 1987, p. 476), it will be argued here that such a right is not necessary to the social function of moral rights.

The resulting wording of Article 6bis of the Berne Convention (the article providing moral rights) in 1928 was:

(1) Independently of the author's economic rights, and even after the transfer of the said rights, the author shall have the right to claim authorship of the work and to object to any distortion, mutilation or other modification of, or other derogatory action in relation to, the said work, which would be prejudicial to his honor or reputation.

(2) The rights granted to the author in accordance with the preceding paragraph shall, after his death, be maintained, at least until the expiry of the economic rights, and shall be exercisable by the persons or institutions authorized by the legislation of the country where protection is claimed. However, those countries whose legislation, at the moment of their ratification of or 
accession to this Act, does not provide for the protection after the death of the author of all the rights set out in the preceding paragraph may provide that some of these rights may, after his death, cease to be maintained.

(3) The means of redress for safeguarding the rights granted by this Article shall be governed by the legislation of the country where protection is claimed.

Moral rights in copyright, in accordance with the Berne Convention, then, must include at least the right to attribution or paternity and the right to integrity, but may include other rights. These rights must be legislated as permanent, nontransferable rights of the author whereas, at any time, an individual or organization other than the author may well hold the economic rights to an author's work. Although the original proposal of the Italian delegation in 1928 defined these rights as "not time limited," the Berne Convention actually accepts any length of protection as long as these rights last at least through the author's lifetime. Finally, these moral rights are to attach to all works to which the economic rights attach.

\section{b) Canada as an early adopter}

Canada became, for the first time in its own right, signatory to the Berne Convention at the Rome Copyright Convention in $1928 .{ }^{24}$ Three years after moral rights were added to the Berne Convention at that Rome Convention, in 1931, Canada amended

\footnotetext{
${ }^{24}$ It may be recalled that, prior to this, Canada had been part of the Berne environment through Great Britain.
} 
its Copyright Act $(1931$, s.5) to add them. Canada thus became the first common law country to introduce moral rights into its domestic legislation. The wording was virtually identical to the wording of the 1928 Berne Convention. ${ }^{25}$

A number of other countries have eventually followed suit by adding moral rights provisions to their copyright legislation. India was another fairly early adopter (Eagles and Longdin, 2004, p. 216). ${ }^{26}$ France, where, as described, moral rights had for sometime been recognized by the courts, only added moral rights provisions to its copyright legislation in 1957 (Loi n ${ }^{\circ}$. 296). England only more recently followed suit by amending its legislation in 1988 to include limited moral rights in some situations (Copyright, Designs and Patents Act (U.K.)). The last century, therefore, saw a slow evolution of moral rights legislation in the Western world.

Canada revised its moral rights provisions in 1988, and completely reworded them, to include what can be identified as three distinct types of moral rights: the right to attribution or paternity and the right to integrity in the work (which, as described, had already been protected, albeit in another form, ${ }^{27}$ since 1924) and the right to association

\footnotetext{
${ }^{25}$ The following wording, which was virtually identical to the Berne Convention wording as it then was passed:

Section twelve of the said Act is hereby amended by adding thereto the following subsection: (5) Independently of the author's copyright, and even after the assignment, either wholly or partially, of the said copyright, the author shall have the right to claim authorship of the work, as well as the right to restrain any distortion, mutilation or other modification of the said work which would be prejudicial to his honour or reputation.

${ }^{26}$ Like Canada, India, another former British colony, passed moral rights legislation as it joined the Berne Convention in its own right.

${ }^{27}$ It may be noted in the quotation below that the right to attribution or paternity is modified after the 1988 amendments in Canada in two ways: first, it must be "reasonable in the circumstances" for attribution to occur, and second, it arises in connection with an act mentioned in s.3. S.3 is the section setting out the economic rights in a work. In particular, in s. 3 of the Canadian statute, it provides that the economic rights arise in connection with the whole work or "any substantial part thereof." The Canadian provisions illustrate the fact that moral rights need not be legislated such that one must be concerned with them (or, for that matter, the economic rights) in connection with quotation of insubstantial portions of works. This put to rest a concern raised by Hazel Bell (2003) that moral rights inevitably have a censoring effect on scholarship.
} 
(which was added in 1988). The terminology and arrangement in the current Canadian legislation are somewhat confusing, however, in terms of identifying the three rights in language that parallels the terminology used by other authorities. The right to attribution or paternity appears in the Canadian statute as:

s.14.1(1) The author of a work, has ... in connection with an act mentioned in section 3, the right, where reasonable in the circumstances, to be associated with the work as its author by name or under a pseudonym ...

The right to integrity appears as:

s.14.1(1) The author of a work, has, subject to section 28.1(1) the right to the integrity of the work ...

and

s.28.1(1) The author's right to the integrity of a work is infringed only if the work is, to the prejudice of the honour or reputation of the author, (a)distorted, mutilated or otherwise modified.

And, finally, the newer right to association (McKeown, 2000 and Sterling, 1999), still using the language of "integrity," appears as:

s.28.1(1) The author's right to the integrity of a work is infringed only if the work is, to the prejudice of the honour or reputation of the author, 
(b) used in association with a product, service, cause or

institution.

As described, development of moral rights in any domestic law lagged

considerably behind the development of the economic rights in copyright and it was not until fifty years after the first Berne Convention that consideration was given to the inclusion of moral rights provisions in this original international agreement on copyright. Even now, while "[m]ost of the world's copyright systems now incorporate or attach a moral rights component these vary widely, not only in detail but also in their origins and theoretical underpinnings." (Eagles \& Longdin, 2004, p. 210). The United States, which is now a signatory to the Berne Convention and leading proponent of strong foreign and international intellectual property protection, still does not have significant moral rights provisions in its copyright legislation. ${ }^{28}$ In fact, the inclusion of moral rights protection in the Berne Convention was one of the stumbling blocks for many years to the accession of the United States to the Convention (Sterling, 1999, p. 280). And, indeed, the United States was instrumental in ensuring that the TRIPS Agreement does not include moral

\footnotetext{
${ }^{28}$ In 1990 the United States enacted the little-used Visual Artists' Rights Act. The statute only applies to original works of art where there are 200 or fewer signed and numbered reproductions of that art - and does not apply in the digital context. The enactment has a further huge gap in its already limited scope: in defining the works of visual art to which it applies, the legislation states, "a work of visual art does not include any work made for hire." (s.101). This latter provision neatly avoids what many Americans perceive as a problematic situation, in which the artist "author" might disagree in a given situation with the "employer" owner of the economic rights in a work, by, in effect, providing no moral rights at all in an employment situation. This American enactment, then, sidesteps a major tenet inherent in the Berne Convention conception of moral rights: the moral rights of the artist are to be independent of the economic rights in copyright - the moral rights are meant to be able to rest in the author's hands even when the economic rights rest elsewhere. The rights under this American legislation last for the artist's lifetime and artists are permitted to waive their rights. It should be noted that, although very narrow, it appears that a number of American libraries have had experience with this legislation in terms of dealing with sculptures, murals or other art decoration (see Gasaway, 2002).
} 
rights. ${ }^{29}$ Moral rights protection has spread slowly, both more slowly and more recently than protection of the economic rights in copyright. There are, however, inherent reasons why moral rights protection should be increasingly embraced by nations in the emerging information age.

\section{c) The Public Purpose of Moral Rights}

Despite the fact that Canada was the first common law country to codify moral rights, and significantly expanded moral rights provision in 1988, no coherent theory or purpose for moral rights has been articulated in Canadian government policy documents.

It has been briefly stated a few times that the purpose of moral rights is to protect the reputation of the author (Consumer and Corporate Affairs Canada, 1984 p. 26; House of Commons Debates, 1988, p.127600; Nordicity Group, 1994, p. 33). Canadian policy makers and theorists adhering to this position are appealing once again to the romantic conception of the author (discussed earlier in connection with the economic rights in copyright). Moral rights provisions, according to this theory, assume a bond between the author and the work. In order to preserve integrity for the author, one must preserve the integrity of the work or use the work as the author intended (the right of association). This theoretical justification would be consistent with the approach, emanating from civil law countries, ascribe moral rights to protection of the personality of the author. For example, the bond that exists between the author and the work is expressed by Sarraute, in his discussion of moral rights in France:

\footnotetext{
${ }^{29}$ On the other hand, Article 6bis of the Berne Convention (moral rights), was not left out of the incorporation by reference of the Berne Convention into the North American Free Trade Agreement [NAFTA] between the United States, Canada and Mexico in 1994 and so, under NAFTA, though not under TRIPS, the United States is obliged to go much further to fully implement its Berne Convention commitment to moral rights for authors.
} 
It includes non-property attributes of an intellectual and moral character which give legal expression to the intimate bond which exists between a literary or artistic work and its author's personality; it is intended to protect his personality as well as his work $(1968$, p. 465$)$.

Reeves Van Kirk confirms this position, noting: "French case law and statutes are permeated with the humanistic, even metaphysical notion that a creative work is, much more than an item of property, an extension of the very personality of the creative artist" (1984, p. 7).

As compelling and romantic as this argument may be, it is inconsistent with the stated government objectives for the copyright regime as a whole in Canada. In a policy statement made before the 1988 amendments to the Copyright Act, the Canadian government made it explicit that there were two primary goals for copyright reform: (1) to encourage creative work and (2) ensure the greatest number of Canadians could benefit from the advances in technology (Department of Communications, 1984, p. 2). The relationship between the moral rights provisions and the stated goals of the copyright reform effort is not explained in the documents.

In order for the Canadian government to be consistent with historical tradition and its own stated purposes for the Copyright Act and government policy in the governance of information, there must be a public purpose or benefit to moral rights. And, indeed, more generally, Gary Lea (2001-2) has concluded, from his review of the origins of moral rights and their modern status, that "the claims that moral rights are not a public interest issue and that they have nothing to do with economic or marketplace matters because of their personal, non-pecuniary nature are ... not sustainable (p.77)". 
There has, in fact, been some limited articulation of a public purpose for moral rights in Canada. Consumer and Corporate Affairs argued, prior to the 1988 Copyright Act amendments, that the right of paternity could potentially protect both the author and the public. The right of paternity was said to work not only for the protection of the author "but also for the public, which has an interest in not being misled as to the origin of a work" (Consumer and Corporate Affairs, 1984, p. 26). At about the same time, outside government, the Association of Universities and Colleges of Canada, also recognised that the public benefits from moral rights legislation $(1985$, p. 5). The Association also noted that moral rights could protect Canada's cultural and artistic heritage since the author's right to the integrity of the work could help to preserve the work but, it said, this purpose should be more clearly articulated (1985, p. 5).

The precise public interest in moral rights remains to be demonstrated. The social bargain for granting moral rights to authors cannot be the same as that argued for the economic rights in copyright: it cannot be said, as it can be in the arena of the economic rights, that the creation of moral rights has created an incentive for the further distribution of works by industrialized processes beyond that which can occur by pre-industrialized methods. Indeed, when the holder of an economic interest afforded by copyright is different from the author, who continues to control the moral rights, the moral rights can be a limitation on the power of the copyright holder (Wilkinson, 2003-4, p.44; Lea, 20012) and on the power of the copyright holder to grant further rights or uses. ${ }^{30}$ Since moral

\footnotetext{
${ }^{30}$ Mark Bide (2003) cites examples on the web where authors have given notice that a work may be freely copied and distributed, but only "as long as it is not altered in any way," (p.107, italics in the original), that is, giving permission concerning their economic rights to control copying and distribution, but only on condition that their moral right, the right to integrity, is respected. Nicholas Joint (2006) points out, in the British context, that certain changes to British copyright legislation has made it easier for libraries to make copies to accommodate the visually impaired - but those changes did not override the moral rights of
} 
rights do not create the same incentives as the economic rights in copyright do, the existence of moral rights does not serve society by encouraging a larger dissemination of information (which is the social benefit derived from the economic rights). Therefore, society does not receive any enhanced access to information from the existence of moral rights.

Research has established, however, that individuals need more than access to various sources of information in order to have their information needs satisfied, they also need to be able to select between competing sources of information (Lynch, 2001, p. 16; Wilkinson, 2001, p. 272-274). Individuals need to be satisfied about the authority behind a particular information source: obviously where there is an information need, the ability to personally judge the accuracy of sources located will be lacking. ${ }^{31}$

The ability to identify source (and, therefore, to judge the authority of the source) will be a particularly important requirement in an era when the available containers of information are all representational: when there may be many aspects of an idea or fact presented through various representations. As Heather MacNeil discusses in an archival context:

Records are viewed as a source of information that permit us to make inferences about the real world. Because they are assumed to reflect events in the real world, records depend for their reliability on the claim of the recordkeeper to have been present at those events. Accordingly,

authors and so libraries must exercise their new rights while still ensuring that the rights of attribution and integrity held by the authors of works are not impaired.

${ }^{31}$ If you know in and of itself that a piece of information is true, then you don't have a need to know that piece of information - if you must rely on an external source to supply you with information, its accuracy must be unknown to you and therefore its source is important to you in order to judge its reliability. As further discussed below, the development of the law of trademark in the commercial environment of goods is another development serving a similar social purpose. 
the methods for assessing record trustworthiness aim to ensure that the record accurately reflects those events, and that it is uncontaminated by the distorting influence of bias, interpretation, or unwarranted opinion on the part of recordkeeper (MacNeil, 2000, p. 115).

In a rigidly hierarchical society, where elites control the channels of information, the containers of information may not need to be identified individually by users in order to confirm their authority and be accepted as satisfying information needs. The Church in the Middle Ages, for example, controlled many of the distribution channels in Europe. Users of information who questioned the veracity of the sources being distributed by the Church were charged with being unorthodox (Randall, 2001 p. 33). Secular information has also historically been controlled by elites. Demonstration of the authority of the sources of information was part of the origin of documents "under seal" (MacNeil, 2000, p. 5). Official seals were used on documents, by members of the elite, in order to ensure the authority of the documents. ${ }^{32}$

In the rapidly evolving society of the industrial and print revolutions, other indications of the authority of information became established in order to minimize reliance upon misinformation and ensure that wider information dissemination pushed forward the progress of society (Hughes, 1999, p 923-1010). These indications included identification of works with the presses and publishers from which they emanated. However, even in the nineteenth century, presses were proliferating. In library and information science terms, there was an increasing problem with establishing the reliability of "grey literature," literature emanating from publishers or presses that were

\footnotetext{
${ }^{32}$ Heather MacNeil notes that archiving itself was also controlled and limited to those in authority (2000, p. 2).
} 
not well known. Questions about the authority of texts and of other containers of information were beginning to arise. Concomitantly, the notion of moral rights in copyright appeared.

\section{d) The new bargain: The role of the rights of paternity and integrity}

Analysis of the underlying effects of the moral rights and economic right regimes indicates that the two are both involved in influencing the flow of information in a society. However, their roles are distinct, because each regime is related to a different aspect, or property, of the containers of information. Economic rights affect the supply of information that is available and hence access to information in a society, and moral rights affect the information seeker's ability to judge the quality of the available information sources and to thus select from amongst competing sources.

Moral rights strike a balance between the right to transform a work for profit or creativity and the right to the integrity of the work which will preserve its cultural or social value. Moral rights can be invoked by an author to oppose an economic rights holder's exploitation of the work in a way deemed to harm the reputation of the author. Furthermore, where a moral rights regime is in place, an economic rights holder can exercise the economic copyright to distribute a work only so long as the work is attributed to the author. Adaptation of a work through the exercise of the economic right of copyright, for further profit, can be limited if it prejudices the integrity of the author or the author's work. Similarly, moral rights, as legislated in Canada, permit authors to 
object to the use of their works to promote particular products or services, even though they have no economic copyright interest or private property interest in the works.

What is the social bargain that has permitted the moral rights regime to endure and spread?

The right of paternity or attribution serves society's interest in ascertaining authority and identifying works with a particular source. The right of an author to be known by name or pseudonym, when exercised by the author, can contribute an indication of authority to a work. ${ }^{33}$ Its existence assists the public by identifying a work with a particular source: its author. In return, the authors of works are given particular unassignable elements of control over their creativity despite the separate existence of the economic copyright interests, which are designed to be transferable, and which, in any case, are not necessarily vested by the law in the creators themselves (for example, in the employment situation).

As the right of paternity does, the right of integrity also serves the public interest. Justin Hughes notes that critics of strong intellectual property regimes focus upon users' rights to access intellectual works (1999). The defence of users' rights always centres upon the need to access works to transform, adapt or use intellectual property in order to produce new works or new meaning. Hughes does not dispute the need for such activity but he fears that in focusing upon the production of new works, another user interest is ignored. Users, he argues, are also interested in the stability of meaning or value of

\footnotetext{
${ }^{33}$ Frequently the paternity right has also been taken to include the author's right to remain anonymous (see, for example, Canada's s.14.1, which is quoted in part above. The entire section as enacted includes not only the quoted "right, where reasonable in the circumstances, to be associated with the work as its author by name or under a pseudonym" but also the concluding "right to remain anonymous." The theory of moral rights being described here does not recognize the option of the author to remain anonymous as a valid contribution to the system of moral rights, although it may well be appropriate legislation for a country to have in place for other reasons (Wilkinson, 2006).
} 
cultural products. In other words, the user is interested in preserving the integrity of the work.

While the rights of paternity and integrity are the rights that the international community has enshrined in the Berne Convention, there are, as mentioned above, other rights which can contribute to the function of moral rights but which have not been universally adopted. For example, as quoted earlier, the Canadian legislation includes a right of association. ${ }^{34}$ This right of association permits the authors to object to the use of their works to promote a product or service, even though they may have no economic copyright interest or private property interest in the work. They can thus ensure that the public reputation of their work is reliably as they intend. It thus provides further assurance to the public by reliably protecting the author's reputation. ${ }^{35}$

The rights of paternity, integrity and association can be defended as serving the public's interest in creating legal assurances of the sources of works in order that members of the public may assess the authority of those works. The right to integrity preserves the author's right to control the content of the work and thus the public's right to be assured that a work represented to emanate from that author is in fact as the author constructed it. The right to paternity or attribution allows an author to insist that her or his identity is attached to the work and thus functions in much the same way as trademark is intended to function (as a reliable indication of source for the public). The right of

\footnotetext{
${ }^{34}$ It has been argued that this right to association is not a new or different moral right but is simply an extension of the right of the author to protect his or her integrity by protecting the integrity, not just of a particular work, but of the whole of her or his oeuvre by ensuring that no element of contextual placement of any work is able to obscure the author's intended context (see Le Nordet, Inc. v.82558 Canada Ltee (1978), decided under Canada's Copyright Act before the 1988 amendments, and see, further, Goudreau (1994)). However, the language of the Canadian statute since 1988 appears to lead to possibilities beyond the concept of integrity as embedded in the Berne Convention.

${ }^{35}$ In a similar vein, in France, where moral rights are perpetual and inherited after the author's death, the granddaughter of artist Henri Rousseau successfully objected to the use of a reproduction of one of his paintings in a promotional display in a Paris department store (Merryman and Elsen, 1987,p.155).
} 
association permits the author to protect the integrity of the work by ensuring that no contextual displacement changes the meaning of the work. ${ }^{36}$ Moral rights provisions are an attempt to find a balance between the incentive to benefit from the commercial adaptation or exploitation of the work and the preservation of the social significance of the work. This is a balance similar to, but distinct from, the balance struck by the economic rights in copyright. Moral rights are private rights that should be granted to the author but are ultimately designed to serve the interests of the public. They, like the economic rights in copyright, are private rights for public ends.

The eighteenth century information needs of societies caught up in the industrial economy were met through the economic rights in copyright in combination with authority controls exercised by elites. Since the late nineteenth century, revolutions in communications technology have caused another shift in our social and economic fabric. In the twentieth century, the sources of information multiplied and the channels of information distribution were similarly augmented, and one important result has been the decline in the ability of elites to provide the imprimatur of authority on the dissemination of information. It is perhaps not surprising, then, that the development of the moral rights regime lagged behind the development of the copyright regime.

In the twenty-first century, revolutionary technology is again the engine driving a "new economy" - but specifically, now, communications and information technology. The new wealth is being created, not in the industrialized processes of the industrial and

\footnotetext{
${ }^{36}$ While the right of association can be analyzed, as we have done here, as connected with the maintainance of a recognizable authority in a work, this connection to the work is more indirectly connected to a particular work than the connections which we have established in the cases of the rights of paternity and integrity. While we agree that the right of association is a possible element of a moral rights regime, we do not argue that the right of association is a necessary element of the moral rights regime.
} 
print revolutions, but in the information flows (Machlup, 1983) ) $^{37}$ the new information revolution. As Bruce Doern and Markus Sharaput describe in their institutional analysis of the Canadian intellectual property policy environment, the Canadian Intellectual Property Office, the Commissioner of Patents and the Registrar of Trademarks have emerged from almost total obscurity as technical operating agencies in the 1990's to agencies now very important to Canada's capacity to be both innovative and internationally competitive (2000, p. 99). Suddenly the ownership and control of ideas and facts are not the drivers permitting the new wealth to be created, they are the new wealth.

As a result of this shift, the need for the social and economic roles played by moral rights has been increasing. Paul Vandoren, for example, specifically recognizes possibilities for increasing exercise of moral rights, although not really articulating why this role should be given to the authors and artists he identifies:

Modifications and adaptations of existing works and protected services have never been as easy as they are today in the digital environment, due to the new technologies. This trend will continue. We may see the day where almost anybody could change the colours of a film or replace the heads of artists and, then, send the film back on the network.

Whilst these technological innovations are applauded by certain sectors, it is not a surprise that they are seen with some unease by others authors and artists. We may thus face a situation in which rightholders will make more use of their moral rights... (Vandoren, 1996, p. 165).

\footnotetext{
${ }^{37}$ Fritz Machlup first articulated the distinction between "information" as a concept implying an objective transfer process whereas "knowledge" implies a subjective state.
} 
A few years earlier, Kathleen Lu (1994)urged the inclusion of a general moral rights regime in American law for virtually the same reasons.

The system of a grant of private rights (moral rights) by the state to serve the public's need for authority in information is exactly the same approach as was taken in the eighteenth century to the need to assure availability of information by granting private rights in the economic rights in copyright. As is the case for the economic rights, the states relies upon those who have been given the rights (authors, in the case of moral rights, and rightsholders, in the case of economic rights) to exercise their rights, and thus influence the public information environment. Not all holders of the economic rights in copyright exploit their rights: many people leave their writings or other works undistributed, unpublished and unused, as do their heirs. However, as has been illustrated in the foregoing, the institution of economic rights in copyright has had a profound effect upon the societies governed by such law. It is to be expected that strong instantiation of moral rights for authors will have a profound effect on the information environment of the future. Under our analysis, authors and artists should be encouraged to exercise their moral rights, particularly in an era when technology makes works fluid and impermanent, in order to give the public the opportunity to understand and evaluate the origins of particular works.

Paradoxically, internationally, there has been a trend which may actually reflect increasing neglect of moral rights rather than an embracing of these provisions. Even in countries where moral rights provisions exist, such as Canada, these rights may have suffered erosion. Canada, for example, in its 1988 amendments, introduced a waiver clause to its moral rights legislation (Copyright Act 1985, s. 14.1(2)). Such a clause may 
greatly weaken the rights of authors because they may easily be required to waive their rights as a condition of publication, ${ }^{38}$ a plausible scenario given the disparity in bargaining power that traditionally has existed between authors and publishers.

. The United States, now a powerful player in the international intellectual property environment, continues to resist the introduction of moral rights into its copyright legislation. Brian E. Koeberle describes how the American Congress was persuaded in the late 1980 's that American law generally already provided sufficient protection for moral rights and thus the United States needed to make no explicit changes to its copyright legislation in order to comply with the moral rights provisions of the Berne Convention once the United States became signatory to it in 1989 (Koeberle, 1989). On the contrary, many believe that American law does not provide moral rights protection sufficient to satisfy the Berne Convention (Damich, 1988, Grant, 1992, Ginsburg 2001), despite the subsequent passage of the limited Visual Artists' Rights Act (1990). And, again, it must be recalled that it was through the express influence of the United States that the moral rights obligations of the Berne Convention were not incorporated into the TRIPS (Agreement on Trade Related Aspects of Intellectual Property Rights), which is appended to the World Trade Organization Agreement of 1994 and incorporates the Berne Convention (art. 9(1)) except for the one section of the Berne Convention, Article 6bis, which provides for moral rights of the author.

The omission of moral rights from TRIPS has been thought to place moral rights protection on an ambiguous footing (Rajan, 2002, p.190). On the other hand, two earlier

\footnotetext{
${ }^{38}$ See David Vaver (1987).
} 
major public law instruments refer to "moral ... interests resulting from any scientific, literary or artistic production": the Universal Declaration of Human Rights (Article 27(2)) and the International Covenant on Economic, Social and Cultural Rights (Article 15(1) (c)). And the recent WIPO Treaty on Performances and Phonograms (1996), which came into force March 2002, requires rights of attribution and integrity for performers (Article 5).

\section{(e) Is there a substitute for moral rights?}

The lack of enthusiasm which the United States has shown for the moral rights regime may be partially explained by the emphasis that the United States places upon the commercial exploitation of information. In this context, it will be recalled from earlier discussion, the traditional print publishing industry by the twentieth century had, in many jurisdictions, created an imprimatur of quality through the identities of the major publishing houses. As media empires have grown, particularly in the United States, it may be suggested that that function has been assumed by the trademarks of the major entertainment conglomerates. Trademark, in the commercial sphere, functions as the quintessential indicator of the public's sense of source. In a society which reveres trademark and where important information sources are identified in the minds of the public with particular trademarks, there may be less impulse for a strong system of moral rights to be developed to respond to information needs. Of course, such a system would require that those commercial conglomerates maintain control over very significant proportions of the information transfers in society. This possibility may have motivated 
the following rather pessimistic comment, made by American Adam Moore, after reviewing the moral rights regime:

Arguably the creator's rights tradition has played [a] minor role in the formulation and application of Anglo-American systems of intellectual property. Even in those countries where these rights are codified in the law, they are apt to be overshadowed by the aforementioned economic rights and incentive based social progress arguments. ... The globalization of intellectual property, rapid growth of digital networks, and expanding power of multinational corporations, have pushed systems of intellectual property away from theoretical foundations and back toward privilege (2004, p. 204).

Of course, as argued herein, it may be in the pragmatic, economic interests of societies, now, to limit the privilege of elites created by the technology of the industrial revolution precisely through the strengthening of the moral rights regime in order to assist the public in identifying reliable and relevant information for their needs. Such a move would foster the social and economic conditions necessary for efficient and effective information transfer, which appears to be prerequisite to success in the new age of communications.

In a more distributed information environment, perhaps such as the internet is providing, and as trademarks come to represent increasingly diverse portfolios of goods and services, trademark law may no longer adequately serve this information need in society to evaluate the authoritativeness of information sources. Indeed, the American 
Supreme Court made precisely this finding in 2003 when it was held that the American

Lanham Act, governing trademark, could not be used to enforce a claim which was essentially a moral rights claim for paternity (Dastar Corp. v. Twentieth Century Fox Film Corp. et al). The decision held that s.43(a) of the Lanham Act governing trademarks could not be invoked to prohibit copying a work such as a television series (as was at issue in the case) without crediting original creators nor could it be invoked to prohibit misattribution. This leaves the United States beleaguered and creators unprotected from a moral rights perspective, even in industries where trademark itself is prevalent and strong (Landau, 2005).

The United States has had a longer experience than many countries with a limited system of economic rights in copyright: a system which focussed on registration and which had a relatively short period of protection. ${ }^{39}$ Because of the limited nature of American copyright, there came to be a vibrant sense of the public domain, conceived of as an extensive environment in which information transfer was unhampered by the claims of copyright. ${ }^{40}$ For countries like Canada, who have long been members of the Berne Convention, that experience was long ago replaced by one in which the existence of economic rights in works was the norm: copyright arising upon creation of the work and lasting for the author's lifetime plus a further fifty years. The "public domain" was interpreted less as a construct without copyright claims and more as a construct of uses of copyrighted works that lay outside the purview of the copyright holder's control (see

\footnotetext{
${ }^{39}$ The situation in the United States until the reforms of the 1970's began, culminating in Berne membership in 1989. Joining the Berne Convention meant abandoning the system of copyright upon registration since Berne requires copyright upon creation of the work. It also meant adopting a period of protection of at least the life of the author plus 50 years, whereas the United States previously had a period of protection of 28 years with a possible 28 years renewal.

40 As a consequence, many Americans, including librarians, argue that recent copyright legislation in the United States extends copyright far beyond what is necessary to enhance the supply of information to satisfy users' information needs; see, for example, Chalsty (1999) and Cheverie (2002).
} 
Wilkinson, 2003-4). In such an environment, which is now the environment shared by the United States after the extremely rapid changes of the past two decades, it is just as well to have a player independent of the holders of the economic interests in copyright who can advance no less worthy claims in certain circumstances (the author's claims to moral rights) and limit the control of the economic rights holders in the information environment.

For England and Wales, where statutory moral rights protection is greater than in the United States but much more limited than in Canada, Jonathan Griffiths (2006) has explored the continued availability of the common law of the unregistered trade mark as an alternative to statutory moral rights. We argue that, even where trademark remedies may be available, the more appropriate approach in the long term is for countries to focus on their moral rights regimes in the context of the development of copyright. First, it is unlikely, given the precedent of the past, that those who form the elite in the present economy will continue to form the elite as the new information economy emerges fully and law designed to perpetuate the old elites will not ultimately assist nations in the emergence of the new economy. Second, again as demonstrated through the abortive attempts at law that preceded the creation of the economic rights in copyright, law focussed on a model of information flow from the past will ultimately prove ineffective in controlling information transfers in the future.

\section{Conclusion}

As information technology continues to re-shape the future, the distributed, digital environment, where every author is also potentially a publisher and every user is possibly 
also either an author or a publisher (or both), ${ }^{41}$ is challenging the oldest copyright controls, the economic rights. The future may lie precisely in the strengthening of the moral rights regime in order to assist the public in identifying reliable and relevant information for their needs. Such law will foster the economic and social conditions necessary for efficient and effective information transfer. The public interest in moral rights demands not only that moral rights provisions be adopted in law but that these rights should also be expanded.

With the increased possibilities for manipulation of recordings as society experiences digitization, it may be that there is good reason to extend moral rights protection to sound recordings. ${ }^{42}$ Moreover, if digitization puts the authenticity of performers' performances at risk, then it would also seem to be socially desirable to attach moral rights to this area of subject matter as well. ${ }^{43}$

The period of protection for moral rights varies from jurisdiction to jurisdiction at present and needs to be addressed. ${ }^{44}$ Analysis of the social and economic importance of moral rights would lead to the conclusion that moral rights should attach to works for as long as their provenance and authority is an issue for those seeking to make use of the underlying works.

\footnotetext{
${ }^{41}$ As Rajan (2004) notes, "[i]n effect, through technology, in combination with cultural training and values, the audience, too, has become an 'author'." (p.53).

${ }^{42}$ See Bill C-61 of 2008, s.8, intending to add s.17.1 to the current Canadian Copyright Act.

${ }^{43}$ It is more difficult to discern, on its face, any argument based on this analysis that would favour extension of moral rights to broadcasts, broadcasting being an area which has been argued above to involve extensions of channel control rather than ordinary copyright control.

${ }^{44}$ It may be recalled that the Berne Convention leaves the span of protection undefined beyond a minimum expectation that these rights last the lifetime of the author. As mentioned above, this minimum is the period of protection in the American Visual Artists' Rights Act; Canada's period of protection is the life of the author plus fifty years, to match the period of protection of the economic rights in Canada; in France moral rights are protected in perpetuity.
} 
The perspective presented here is that moral rights and economic rights in copyright are best understood as the implementation of information policy designed to further the interests of society in an expanding supply of reliable, available information. The economic rights are designed to address the question of the supply of available information, while moral rights are designed to address the question of making the reliability of that supply ascertainable. The need to assist information users to make these judgements is becoming more urgent in the emerging environment. As Clifford A. Lynch points out:

Highly distributed information dissemination systems like the World Wide Web herald a fundamental change ...Among the consequences of this shift will be a new emphasis on the provenance of data and metadata, and the need for information retrieval systems to permit users to factor in trust preferences about this information (Lynch, 2001, p. 12).

With the growing complexity of the information environment, moral rights will become increasingly important as a guarantee for the authority and the integrity of the work. Moral rights regimes, enshrining at least the author's rights to integrity and paternity, should be embraced and enhanced for this very reason. 
References

Agreement on Trade-Related Aspects of Intellectual Property Rights [TRIPS], Annex 1C to the Marrakesh Agreement Establishing the World Trade Organization, 15 April 1994, 33 ILM 1197 (entered into force 1 January 1996):

http://www.wto.org/english/docs_e/legal_e/27-trips_01_e.htm

Aide, Christopher. (1990). A More Comprehensive Soul: Romantic Conceptions of Authorship and the Copyright Doctrine of Moral Right. University of Toronto Faculty of Law Review 48, 211-228.

Association of Universities and Colleges of Canada. (1985). Comments of the Association of Universities and Colleges of Canada on the White Paper on Copyright Entitled "From Gutenberg to Telidon. Toronto: The Association.

Beattie, John M. and Michael G. Finlayson. (1987). The Struggle for Power: English History 1550-1720. Toronto: Canadian Scholars Press.

Bell, Hazel K. (2003). In Other Words. Journal of Scholarly Publishing 34, 208-213.

Berne Convention for the Protection of Literary and Artistic Works, 9 September 1886, 828 UNTS 221; available from http://www.law.cornell.edu/treaties/berne/overview.html.

Berne Convention for the Protection of Literary and Artistic Works, 9 September 1886, 828 U.N.T.S. 221, Can. T.S. 1998 No.18 (last revised 24 July 1971 and amended on 28 September 1979).

Bettig, Ronald. (1996). Copyrighting Culture: The Political Economy of Intellectual Property. Boulder: Westview Press.

Bide, Mark (2003). Copyright and the Network. Learned Publishing 16, 103-109.

Boyle, James. (1996). Shamans, Software, \& Spleens: Law and the Construction of the Information Society. Cambridge, Mass.: Harvard University Press.

Bowman. J. (2003). Essential Cataloguing. London: Facet Publishing.

Canada. Act to Amend the Copyright Act, Statutes of Canada 1931, c. C-8.

Canada, Bill 28 of 1924, $3^{\text {rd }}$ sess., $14^{\text {th }}$ Parliament.

Canada, Bill 2 of $1925,4^{\text {th }}$ sess., $14^{\text {th }}$ Parliament.

Canada, Bill 3 of $1926,1^{\text {st }}$ sess., $15^{\text {th }}$ Parliament. 
Canada, Bill 45 of $1927,2^{\text {nd }}$ sess., $16^{\text {th }}$ Parliament.

Canada, Bill C-60 of 2005. An Act to Amend the Copyright Act, $1^{\text {st }}$ sess., $38^{\text {th }}$ Parliament.

Canada. Bill C-61 of 2008, An Act to Amend the Copyright Act, $2^{\text {nd }}$ sess., $39^{\text {th }}$ Parliament. First Reading June 17, 2008.

Canada. Copyright Act/ Loi sur le Droit d'Auteur, Revised Statutes of Canada, 1985, c. C-42, as amended.

Canada. Copyright Act, S.C. 1921, c. 24.

Canada. Department of Communications. (1984) Copyright and the Cultural Community. Ottawa: Department of Communications.

Canada. Department of Consumer and Corporate Affairs. (1984). From Guttenberg to Telidon: A White Paper on Copyright. Ottawa: Ministry of Supply and Services.

Canada. House of Commons Debates (3 February 1988), 12600.

Chappell v. Purday (1845), 14 M\&W 303.

Chalsty, Deborah (1999). The Economic Logic of Copyright. Legal Reference Services Quarterly 17, 145-159.

Cheverie, Joan F. (2002). The Changing Economics of Information, Technological Development, and Copyright Protection: What are the Consequences for the Public Domain? The Journal of Academic Librarianship 28, 325-331.

Damich, Edward J. (1988). The Right of Personality: A Common-Law Basis for the Protection of Moral Rights of Authors. Georgia Law Review 23, 1-96.

Dastar Corp. v. Twentieth Century Fox Film Corp.et al. (2003) 539 US 23 (United States Supreme Court).

Drassinower, Abraham. (2003). A Rights-Based View of the Idea/Expression Dichotomy in Copyright Law. Canadian Journal of Law and Jurisprudence 16, 3-21.

Doern, G. Bruce and Markus Sharaput. (2000). Canadian Intellectual Property: The Politics of Innovating Institutions and Interests. Toronto: University of Toronto Press.

Eagles, Ian and Louise Longdin. (2004) Technological Creativity and Moral Rights: A Comparative Perspective. International Journal of Law and Information Technology, 12, 209-236. 
Eisenstein, Elizabeth. (1979). The Printing Press as an Agent of Change. Cambridge: Cambridge University Press.

France. Loi no. 296 du 11 mars, 1957.

Gasaway, Laura N. (2003). Libraries, Users, and the Problem of Authorship in the Digital Age. Depaul Law Review, 52,1193-1227.

Gasaway, Laura N. (2002) Copyright and Moral Rights. Information Outlook 6, 40-41.

Ginsburg, Jane. (2001). Have Moral Rights Come of (Digital) Age in the United States?. Cardozo Arts and Entertainment Law Journal, 19, 9-49.

Goudreau, Mistrale. (1994) Le droit moral de l'auteur au Canada. R.G.D., 25, 403-428.

Grant, David R. (1992). Rights of Privacy - An Analytical Model for the Negative Rights of Attribution. Utah Law Review, 529, 529-564.

Griffiths, Jonathan (2006). Misattribution and Misrepresentation - the Claim for Reverse Passing Off as "Paternity” Right. Intellectual Property Quarterly 34, 1-15.

Hesse, Carla. (1990) Enlightenment Epistemology and the Laws of Authorship in Revolutionary France, 1777-1793. Representations 30, 109-137.

Hughes, Justin. (1999) Recoding Intellectual Property and Overlooked Audience Interests. Texas Law Review, 77, 923-1010.

International Union for the Protection of Literary and Artistic Works. (1986) Conference in Rome, 1928 - Memorandum by the Italian Delegation (Moral Rights). In World intellectual Property Organization, The Berne Convention for the Protection of Literary and Artistic Works from 1886 to 1986, 162-164. Geneva: International Bureau of Intellectual Property.

International Union for the Protection of Literary and Artistic Works. (1986). Conference in Rome, 1928 - II. Reports of the Sub-Committees 1. Sub-Committee on Moral Rights. In World intellectual Property Organization, The Berne Convention for the Protection of Literary and Artistic Works from 1886 to 1986, 162-164. Geneva: International Bureau of Intellectual Property.

Joint, Nicholas (2006). Libraries, Digitization and Disabilities. Library Review 55, 168172.

Katz, William. (1997) Introduction to Reference Work Vol. 1. New York: McGraw-Hill.

Koeberle, Brian E. (1989). Play It Again Samantha? Another Argument for U.S. Adherence to Article 6bis of the Berne Convention. Duquesne Law Review, 27, 609-624. 
Landau, Michael.(2005) "Copyrights, Moral Rights, and the End of the Right of Attribution under US Trademark Law." International Review of Law, Computers and Technology ${ }_{2}$ 19, 37-64.

Le Nordet, Inc. v. 82558 Canada Ltee [1978] Que. S.C. 904.

Lea, Gary (2001-2). Moral Rights: Moving from Rhetoric to Reality in Pursuit of European Harmonization. The Yearbook of Copyright and Media Law, 61-84.

Lu, Kathleen (1994). Technological Challenges to Artists' Rights in the Age of Multimedia: Tthe Future Role of Moral Rights. Reference Services Review 22, 9-19.

Lynch, Clifford A. (2001). When Documents Deceive: Trust and Provenance as New Factors for Information Retrieval in a Tangled Web. Journal of the American Society for Information Science and Technology, 52, 12-17.

Machlup, Fritz. (1983) Semantic Quirks in Studies of Information. In F. Machlup \& U. Mansfield (Eds.), The Study of Information: Interdisciplinary Messages (pp. 641-671). New York: Wiley.

MacNeil, Heather. (2000). Trusting Records: Legal, Historical, and Diplomatic Perspectives. Dordrecht: Kluwer Academic Publishers.

Masiyakurima, Patrick (2005) The Trouble with Moral Rights. The Modern Law Review, $68,411-434$.

McKeown, John S. (2000). Fox Canadian Law of Copyright and Industrial Designs (3d ed.). Scarborough: Carswell.

Merryman, John Henry, and Albert Elsen (1987). Law, Ethics and the Visual Arts. Philadelphia: University of Pennsylvania Press.

Moore, Adam. (1997). Toward a Lockean Theory of Intellectual Property. In Adam Moore_(Ed.) Intellectual Property: Moral, Legal, and International Dilemmas (pp.81106). New York: Rowman \& Littlefield Publishers Inc.

Moore, Adam. (2003). Intellectual Property: Theory, Privilege, and Pragmatism. Canadian Journal of Law and Jurisprudence, 16, 191- 216.

North American Free Trade Agreement [NAFTA], 17 December 1992, Can.T.S. 1994 No.2, 32 I.L.M.289 (entered into force January 1, 1994).

Nordicity Group. (1994). Study on New Media and Copyright: Final Report. Ottawa: Minister of Supply and Services Canada. 
Patterson, Lyman. (1968) Copyright in Historical Perspective. Nashville: Vanderbilt University Press.

Rajan, Mira T. Sundara. (2002) Moral Rights in the Digital Age: New Possibilities for the Democratization of Culture. International Review of Law, Computers and Technology, 16, 187-197.

Rajan, Mira T. Sundara (2004). Moral Rights in Information Technology: A New Kind of 'Personal Right'? International Journal of Law and Technology 12, 32-54.

Randall, Marilyn. (2001). Pragmatic Plagiarism: Authorship, Profit and Power. Toronto: University of Toronto Press.

Ricketson, Sam. (1987). The Berne Convention for the Protection of Literary and Artistic Works: 1886-1986. London: Centre for Commercial Law Studies, Queen Mary College.

Samuels, Edward. The Illustrated Story of Copyright. New York: St. Martin's Press, 2000

Sarraute, Raymond. (1968). Current Theory on the Moral Right of Authors and Artists Under French Law. American Journal of Comparative Law 16, 465-486.

Sterling, J.A.L. (1999). World Copyright Law. London: Sweet \& Maxwell.

Stone, Lawrence. (1972). The Causes of the English Revolution 1529-1642. London: Routledge and K.Paul.

Théberge v. Galerie d'Art du Petit Champlain Inc. [2002] S.C.J. No. 32 (Supreme Court of Canada)

United Kingdom. England. 1 Rich.III, c.9 (1498)

United Kingdom. An Act for the Encouragement of Learning and for Securing the Property of Copies of Books to the Rightful Owners Thereof, (1709) 8 Anne, c.19 [Statute of Anne].

United Kingdom. Copyright, Designs and Patents Act, 1988, c.iv, ss.77-89.

United Kingdom. Licensing Act of 1662. 13 \& 14 Car.II, c.33.

United Kingdom. King Henry VIII Proclamation of November $16^{\text {th }} 1538$. Proclamation No. 176 in R.R. Steele (ed.) (1910) Tudor and Stuart Proclamations, 1485-1714 (Oxford).

United Nations. International Covenant on Economic, Social and Cultural Rights. Adopted and opened for signature, ratification and accession by United Nations General 
Assembly Resolution 2200A(XXI) of 16 December 1966 (entry into force January 3, 1976).

United Nations. Universal Declaration of Human Rights. Adopted and proclaimed 10 December 1948. G.A. Res. 217(III), U.N. G.A.O.R., 3d Sess., Supp.No.13, U.N.Doc. A/810.

United States. Constitution. (September 17, 1786). art. I, §8, cl.1.

United States (1946). Lanham(Trademark) Act, 15 U.S.C. $\S \S 1051-1127$.

United States. Copyrights. 17 U.S.C.

United States. Digital Millenium Copyright Act [DMCA] of 1998, Pub.L.No.105-304, 112 Stats,2860, amending 17 U.S.C., anti-circumvention provisions $§ 1201$.

United States. Visual Artists' Rights Act, 1990 Public Law 101-650, U.S. Statutes at Large 104 (1990): 5089, 5128.

Van Kirk, Reeves, Ronald Bauer and Stéphane Lieser. (1984). Retained Rights of Authors, Artists, and Composers under French Law on Literary and Artistic Property. Journal of Arts Management \& Law, 14, 7-30.

Vandoren, Paul. (1996). Copyright and Related Rights in Society. In P. Bernt Hugenholtz (Ed.), The Future of Copyright in a Digital Environment: Proceedings of the Royal Academy Colloquium organized by the Royal Netherlands Academy of Sciences [KNAW] and the Institute for information Law 1995. The Hague: Kluwer Law International.

Vaver, David. (1987). Authors Moral Rights- Reform Proposals in Canada: Charter or Barter or Rights for Creators? Osgood Hall Law Journal 25, 749-786.

Vaver, David. (1991) Some Agnostic Observations on Intellectual Property. Intellectual Property Journal 6, 125- 153.

Wilkinson, Margaret Ann (2001). Information Sources Used by Lawyers in Problemsolving: An Empirical Exploration. Library and Information Science Research, 23, 257276.

Wilkinson, Margaret Ann (2003-4). National Treatment, National Interest and the Public Domain. University of Ottawa Law and Technology Journal, 1, 23-49.

Wilkinson, Margaret Ann (2006). The Public Interest in Moral Rights Protection. Michigan State Law Review, Spring, 193-234.

World Intellectual Property Organization [WIPO] Copyright Treaty, adopted by the World Intellectual Property Organization Diplomatic Conference on Certain Copyright 
and Neighbouring Rights Questions in Geneva, 20 December, 1996, S. Treaty Doc. No. 105-17, 36 I.L.M. 65 (1997) (entered into force 2002).

World Intellectual Property Organization [WIPO] Performances and Phonograms Treaty, adopted by the World Intellectual Property Organization Diplomatic Conference on Certain Copyright and Neighbouring Rights Questions in Geneva, 20 December, 1996, S.Treaty Doc. No.105-117, 36 I.L.M. 76 (1997) (entered into force 2002). 